\title{
The Combination of Neutrophil-to-lymphocyte Ratio and Serum Carbohydrate Antigen 19-9 Level as a Prognostic Indicator in Patients with Recurrent Pancreatic Cancer
}

\author{
TERUHISA SAKAMOTO, HIROAKI SAITO, EI UCHINAKA, MASAKI MORIMOTO, MASATAKA AMISAKI, \\ NARUO TOKUYASU, SOICHIRO HONJO, KEIGO ASHIDA and YOSHIYUKI FUJIWARA \\ Division of Surgical Oncology, Department of Surgery, School of Medicine, \\ Tottori University Faculty of Medicine, Yonago, Japan
}

\begin{abstract}
Background/Aim: We retrospectively investigated the relationship between prognosis and combined neutrophil-to-lymphocyte ratio (NLR) and serum carbohydrate antigen 19-9 (CA19-9) levels in patients with recurrent pancreatic cancer. Patients and Methods: We enrolled 66 patients whose pancreatic cancer recurred. Results: Based on ROC analysis results, the patients were divided into NLR High $(N L R \geq 1.69)$ or $N L R^{L o w}(N L R<1.69)$, and into CA19-9 ${ }^{\mathrm{High}}$ (CA19-9 $\geq 107.95 \mathrm{U} / \mathrm{ml})$ or CA19-9 ${ }^{\text {Low }}$ (CA19-9 <107.95 $U / \mathrm{ml})$. When the patients were grouped by combined NLR and CA19-9, their 2-year survival rates were NLR Low $/ C A 19-9^{\text {Low }}$ : 58.7\%; NLR ${ }^{\text {Low }} /$ CA19-9High or NLR High $/ C A 19-9^{\text {Low }}$ (grouped together): $11.2 \%$; and NLR $\mathrm{High}^{\mathrm{HCA19}} 9^{\mathrm{High}}$ : $0 \%(p<0.0001)$. Finally, in multivariate analysis, the combination of NLR and serum CA19-9 level was an independent prognostic factor in patients with recurrent pancreatic cancer. Conclusion: The combination of NLR and serum CA19-9 level is a useful prognostic indicator for recurrent pancreatic cancer.
\end{abstract}

Pancreatic cancer (PC) is the most aggressive malignancy, with a 5-year overall survival rate of less than 5\%; worldwide, it is the seventh leading cause of cancer-related mortality $(1,2)$. Chemotherapy or radiation therapy had been used to treat patients with recurrent PC, but median survival time after recurrence was only 5.1-6.0 months $(3,4)$. However, recent progress in chemotherapy, such as nabpaclitaxel plus gemcitabine (GEM) and FOLFIRINOX, has been shown to prolong their survival $(5,6)$. Accurate

Correspondence to: Hiroaki Saito, Division of Surgical Oncology, Department of Surgery, School of Medicine, Tottori University Faculty of Medicine, 36-1 Nishi-cho, Yonago 683-8504, Japan. Tel: +81 859386567, Fax: +81 859386569, e-mail: sai10@tottori-u.ac.jp

Key Words: Recurrent pancreatic cancer, neutrophil-to-lymphocyte ratio, prognosis. prediction of prognosis in these patients is needed to determine optimal treatment strategies and prepare patients' expectations.

Serum tumor markers (TMs) are recognized as prognostic indicators in various types of cancers (7-10). Among serum TMs, carbohydrate antigen 19-9 (CA19-9) is the only marker currently recommended for monitoring PC by the National Comprehensive Cancer Network guidelines. Several studies reported the relationship between CA19-9 and survival (1114), which implies that CA 19-9 is a prognostic indicator in recurrent $\mathrm{PC}$ as well.

Although TMs, including CA19-9, are mainly derived from the cancer itself, prognoses of various cancers are also affected by patient-related factors, including inflammation, immunocompetence, and nutrition, with the correlation between inflammation status and cancer prognosis being of particular interest. Reportedly, systemic inflammatory responses are closely associated with development and progression of cancer by the promotion of angiogenesis and increased cancer cell proliferation (15, 16). The neutrophil-to-lymphocyte ratio (NLR), an inflammatory indicator derived from routine blood tests, is a well-recognized prognostic factor in various cancers (1722). Garcea et al. reported that preoperative NLR offered important prognostic information regarding disease-free survival following curative resection of PC (23). However, the prognostic significance of CA19-9 and NLR in recurrent $\mathrm{PC}$ patients remains unclear. Therefore, this study aimed to evaluate the prognostic significance of NLR and serum CA19-9 level in recurrent PC patients. Furthermore, the different origins of TMs and NLR suggested that their combination might be superior to either TMs or NLR alone for predicting prognosis of patients with recurrent PC. The current study, therefore, also aimed to evaluate the prognostic significance of the combination of serum CA19-9 level and NLR in these patients. 


\section{Patients and Methods}

Patients. We retrospectively reviewed records of 103 patients who had undergone pancreaticoduodenectomy or distal pancreatectomy with regional lymphadenectomy for PC at our hospital between January 2005 and December 2016 and found 70 who had developed postoperative recurrence as of March 31, 2018. 4 patients were excluded because either their NLR or serum CA19-9 levels at the time of recurrence were unavailable. Finally, 66 patients were enrolled in this study. The subjects included 44 men and 22 women whose median age was 71.5 years (range $=44-85$ years) at the time of recurrence. Their median follow-up periods were 25.5 months (range=1.7-91.5 months) after surgery and 9.1 months (range=084.5 months) after recurrence. The clinicopathological findings were determined according to the 7th edition of General Rules for the Study of Pancreatic Cancer by Japan Pancreas Society (24). Patients were periodically checked for early recurrence by diagnostic imaging, such as ultrasonography (US), computed tomography (CT), magnetic resonance imaging (MRI), and positron emission tomography (PET). We collected data of serum CA 19-9 levels, peripheral lymphocyte counts, and peripheral neutrophil counts from blood tests performed at the time of recurrence and indicated in the patients' records. The NLR was obtained by dividing the peripheral neutrophil count by the peripheral lymphocyte count.

Among the 66 patients included in this study, 50 patients $(75.8 \%)$ underwent chemotherapy to treat their recurrent PC, including 38 who received GEM-based regimen (GEM alone or GEM plus S-1 or GEM plus nab-paclitaxel), 11 who received S-1 alone and 1 who received uracil-tegafur as first-line therapy, and 15 who also received secondary treatment (FOLFIRINOX, $\mathrm{n}=1$; GEM plus nab-paclitaxel, $\mathrm{n}=1$; GEM plus $\mathrm{S}-1, \mathrm{n}=4$; GEM plus oxaliplatin, $\mathrm{n}=2$; GEM alone, $\mathrm{n}=5 ; \mathrm{S}-1, \mathrm{n}=2)$. Sixteen $(24.2 \%)$ of 66 patients were treated with best supportive care without chemotherapy. Recurrences within 12 months after surgery were classified as early recurrences, and those occurring later than 12 months after surgery were considered late recurrences, according to a previous report (25).

The Tottori University Hospital Ethics Committee approved this study (No. 17A135); informed consent requirements were waived for this retrospective study.

Statistical analysis. The Chi-square test and Fisher's exact probability tests were used to evaluate differences between two groups. Optimal cutoff values for NLR and serum CA19-9 levels with respect to survival were calculated using receiver operating characteristic (ROC) analysis. Survival curves after recurrence were constructed by the Kaplan-Meier method, and the prognostic differences among survival curves were examined with log-rank tests. We used univariate and multivariate analyses of factors considered prognostic of overall survival, with Cox's proportional hazards model. $p$-Value $<0.05$ was considered significant. All statistical analyses were performed using SPSS software (Version 24, SPSS Inc., Chicago, IL, USA).

\section{Results}

Mean NLR and serum CA19-9 level at the time of recurrence were $2.42 \pm 2.57$ and $945.0 \pm 2816.1 \mathrm{U} / \mathrm{ml}$, respectively. No significant correlation between NLR and serum CA19-9 level was found (Figure 1).

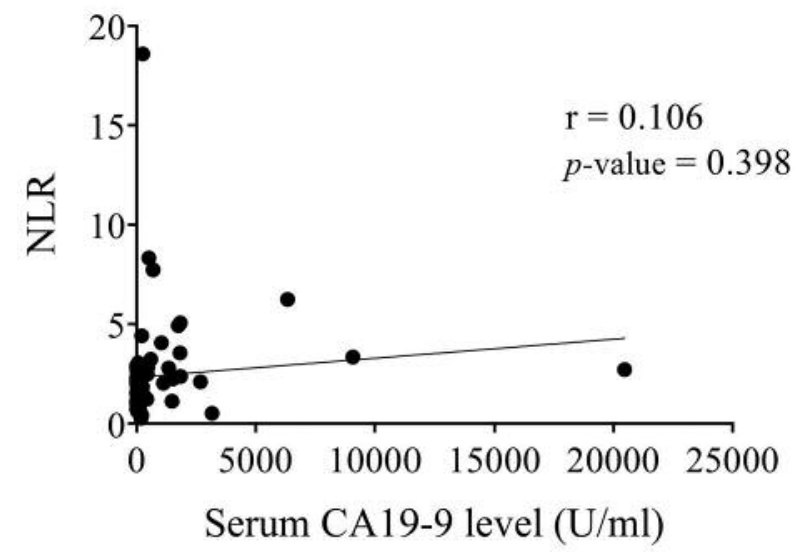

Figure 1. Graph of neutrophil-to-lymphocyte ratio (NLR) and serum carbohydrate antigen 19-9 (CA19-9) level at the time of recurrence. We observed no significant correlation between NLR and serum CA19-9 level.

In ROC analyses of NLR and serum CA19-9 level, optimal cut-off values (highest Youden indices) for 2-year survival were NLR: 1.69, and CA19-9: 107.95 U/ml. Based on these results, patients were grouped as: $\mathrm{NLR}^{\text {High }}(\mathrm{NLR} \geq 1.69 ; \mathrm{n}=36)$ or $\mathrm{NLR}^{\text {Low }}$ (NLR <1.69; n=30); and as CA19-9 ${ }^{\text {High }}$ (CA19-9 $\geq 107.95 \mathrm{U} / \mathrm{ml} ; \mathrm{n}=37$ ) or CA19-9 ${ }^{\text {Low }}$ (CA19-9 <107.95 U/ml; $\mathrm{n}=29$ ). Table I shows correlations among NLR, serum CA19-9 level, and clinicopathological characteristics in patients with recurrent PC. Significant associations were observed between NLR and lymph node metastasis $(p=0.006)$, and between serum CA19-9 level and vascular involvement ( $p=0.03)$. Twoyear survival rates significantly varied by both NLR (NLR ${ }^{\text {High }}$ group: $3.4 \%, \mathrm{NLR}^{\mathrm{Low}}$ group: $40.2 \%, p<0.001$; Figure $2 \mathrm{a}$ ), and CA19-9 (CA19-9 ${ }^{\text {High }}$ group: $3.6 \%$, CA19-9 ${ }^{\text {Low }}$ : $39.4 \%$, $p<0.001$; Figure 2b).

The prognostic significance of the combination of NLR and serum CA19-9 level was then determined by dividing the patients into three groups: NLR ${ }^{\text {Low }} / \mathrm{CA} 19-9^{\text {Low }}$ (Group $\mathrm{A}, \mathrm{n}=17) ; \mathrm{NLR}^{\mathrm{Low}} / \mathrm{CA} 19-9^{\text {High }}$ or $\mathrm{NLR}^{\text {High }} / \mathrm{CA} 19-9^{\text {Low }}$ (Group B, $\mathrm{n}=25$ ); and $\mathrm{NLR}^{\mathrm{High}} / \mathrm{CA} 19-9^{\text {High }}$ (Group C, $\mathrm{n}=24)$. To this end, the patients in Groups $\mathrm{A}, \mathrm{B}$, and C were assigned 0,1 , and 2 , respectively, according to the previous study (26). The AUCs for 2-year survival were NLR: 0.647 $(p=0.059)$, serum CA19-9 level: $0.672 \quad(p=0.027)$, and combination of NLR and serum CA19-9 level: 0.772 $(p<0.001)$, which indicates that the combination of NLR and serum CA19-9 level is more useful than either indicator alone for predicting 2-year survival in these patients (Figure 3). Two-year survival rates were Group A: 58.7\%, Group B: $11.2 \%$, and Group C: $0 \%(p<0.0001$; Figure 4). Finally, in multivariate analysis, the combination of NLR and serum CA19-9 level was an independent prognostic factor for patients with recurrent PC (Table II). 
Table I. Relationships among NLR, serum CA19-9 level, and clinicopathological variables in recurrent pancreatic cancer patients.

\begin{tabular}{|c|c|c|c|c|c|c|}
\hline Variables (n) & $\begin{array}{l}\text { NLR }^{\text {Low }}, \mathrm{n}(\%) \\
\quad 30(100 \%)\end{array}$ & $\begin{array}{l}\mathrm{NLR}^{\mathrm{High}}, \mathrm{n}(\%) \\
\quad 36(100 \%)\end{array}$ & $\mathrm{p}$-Value & $\begin{array}{c}\text { CA19-9Low, n (\%) } \\
29(100 \%)\end{array}$ & $\begin{array}{c}\text { CA19-9High, } \mathrm{n}(\%) \\
37(100 \%)\end{array}$ & p-Value \\
\hline \multicolumn{7}{|l|}{ Age (years) } \\
\hline$<70(27)$ & $13(43.3 \%)$ & $14(38.9 \%)$ & \multirow[t]{2}{*}{0.715} & $15(51.7 \%)$ & $12(32.4 \%)$ & \multirow[t]{2}{*}{0.114} \\
\hline$\geq 70$ (39) & $17(56.7 \%)$ & $22(61.1 \%)$ & & $14(48.3 \%)$ & $25(67.6 \%)$ & \\
\hline \multicolumn{7}{|l|}{ Gender } \\
\hline Male (44) & $19(63.3 \%)$ & $25(69.4 \%)$ & \multirow[t]{2}{*}{0.6} & $19(65.5 \%)$ & $25(67.6 \%)$ & \multirow[t]{2}{*}{0.861} \\
\hline Female (22) & $11(36.7 \%)$ & $11(30.6 \%)$ & & $10(34.5 \%)$ & $12(32.4 \%)$ & \\
\hline \multicolumn{7}{|l|}{ Primary Tumor size $(\mathrm{mm})^{\mathrm{a}}$} \\
\hline$<29.5(35)$ & $18(60.0 \%)$ & $17(50.0 \%)$ & \multirow[t]{2}{*}{0.423} & $17(60.7 \%)$ & $18(50.0 \%)$ & \multirow[t]{2}{*}{0.393} \\
\hline$\geq 29.5$ (29) & $12(40.0 \%)$ & $17(50.0 \%)$ & & $11(39.3 \%)$ & $18(50.0 \%)$ & \\
\hline \multicolumn{7}{|l|}{ Tumor location } \\
\hline Head (45) & $19(63.3 \%)$ & $26(72.2 \%)$ & \multirow[t]{2}{*}{0.44} & $19(65.5 \%)$ & $26(70.3 \%)$ & \multirow[t]{2}{*}{0.681} \\
\hline Body and tail (21) & $11(36.7 \%)$ & $10(27.8 \%)$ & & $10(34.5 \%)$ & $11(29.7 \%)$ & \\
\hline \multicolumn{7}{|l|}{ Lymph node metastasis } \\
\hline Absent (19) & $14(46.7 \%)$ & $5(13.9 \%)$ & \multirow[t]{2}{*}{0.006} & $12(41.4 \%)$ & $7(18.9 \%)$ & \multirow[t]{2}{*}{0.058} \\
\hline Present (47) & $16(53.3 \%)$ & $31(86.1 \%)$ & & $17(58.6 \%)$ & $30(81.1 \%)$ & \\
\hline \multicolumn{7}{|l|}{ Lymphatic involvement ${ }^{b}$} \\
\hline Ly 0/1 (24) & $12(41.4 \%)$ & $12(33.3 \%)$ & \multirow[t]{2}{*}{0.504} & $14(48.3 \%)$ & $10(27.8 \%)$ & \multirow[t]{2}{*}{0.089} \\
\hline Ly $2 / 3(41)$ & $17(58.6 \%)$ & $24(66.7 \%)$ & & $15(51.7 \%)$ & $26(72.2 \%)$ & \\
\hline \multicolumn{7}{|l|}{ Vascular involvement $\mathrm{t}^{\mathrm{c}}$} \\
\hline $\mathrm{V} 0 / 1(31)$ & $16(53.3 \%)$ & $15(41.7 \%)$ & \multirow[t]{2}{*}{0.344} & $18(62.1 \%)$ & $13(35.1 \%)$ & \multirow[t]{2}{*}{0.03} \\
\hline $\mathrm{V} 2 / 3(35)$ & $14(46.7 \%)$ & $21(58.3 \%)$ & & $11(37.9 \%)$ & $24(64.9 \%)$ & \\
\hline \multicolumn{7}{|l|}{ Perineural invasion ${ }^{\mathrm{d}}$} \\
\hline $\mathrm{Ne} 0 / 1(9)$ & $6(20.0 \%)$ & $3(8.3 \%)$ & \multirow{2}{*}{0.28} & $3(10.3 \%)$ & $6(16.2 \%)$ & \multirow[t]{2}{*}{0.72} \\
\hline $\mathrm{Ne} 2 / 3(57)$ & $24(80.0 \%)$ & $33(91.7 \%)$ & & $26(89.7 \%)$ & $31(83.8 \%)$ & \\
\hline \multicolumn{7}{|l|}{$\begin{array}{l}\text { Time to recurrence after } \\
\text { pancreatectomy }\end{array}$} \\
\hline$<12$ months; early (40) & $16(53.3 \%)$ & $24(66.7 \%)$ & \multirow[t]{2}{*}{0.27} & $15(51.7 \%)$ & $25(67.6 \%)$ & \multirow[t]{2}{*}{0.191} \\
\hline$\geq 12$ months; late $(26)$ & $14(46.7 \%)$ & $12(33.3 \%)$ & & $14(48.3 \%)$ & $12(32.4 \%)$ & \\
\hline
\end{tabular}

NLR ${ }^{\text {Low: }}<1.69$; NLR ${ }^{\text {High: }} \geq 1.69$; CA19-9Low: <107.95; CA19-9High: $\geq 107.95$. adata not available for 2 patients; bympatic involvement: ly 0-3,

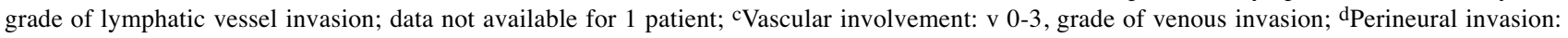
ne $0-3$, grade of perineural invasion.

\section{Discussion}

The present study demonstrates that both NLR and serum CA19-9 level at the time of PC recurrence are useful for predicting prognosis and supports the notion that both tumorrelated markers and patient-related inflammation markers affect prognosis.

Neutrophils play important roles in systemic inflammatory response, which affects both tumor development and metastasis. In response to cytokine stimulation, neutrophils can diverge towards antitumor (N1) or protumor (N2) phenotypes (27). In the acute inflammation state, neutrophils are activated to exert an antitumor effect, whereas in chronic inflammation, neutrophils may promote tumor growth and metastasis. Inflammatory cytokines such as G-CSF, IL-6, and TGF- $\beta 1$ can induce the $\mathrm{N} 2$ phenotype in bone marrow and tumor microenvironments (28). In addition, priming with IFN- $\gamma$ and TNF- $\alpha$ can convert the phenotype from N2 to N1 (29). Thereby, neutrophils may exert either an antitumor or protumor function, depending on the profile of inflammatory cytokines. Increased serum concentration of IL-6 was reported in patients with $\mathrm{PC}(30,31)$, which suggests that most of the increased numbers of neutrophils observed in patients with recurrent PC are of the N2 phenotype and may exert a protumor effect. In addition, neutrophils can reportedly induce tumor progression via releasing matrix metalloproteinase-9, which activates angiogenic factors (32, 33). This relationship could explain the correlation between high NLR and poor prognosis in the current study.

High NLR also reflects low lymphocyte count, which is also reportedly related to poor prognosis in various cancers, including PC (34-36). Lymphocytes include CD4 ${ }^{+}$and $\mathrm{CD}^{+}$ $\mathrm{T}$ cells, NK cells, NKT cells, gamma-delta $\mathrm{T}$ cells, and $\mathrm{B}$ cells, which are closely associated with tumor immunity. Therefore, low numbers of those cells are likely associated with impaired tumor immunity, which in turn results in tumor progression. In fact, several studies have associated tumor-infiltrating lymphocytes, such as $\mathrm{CD}^{+}$and $\mathrm{CD}^{+}$ 
a

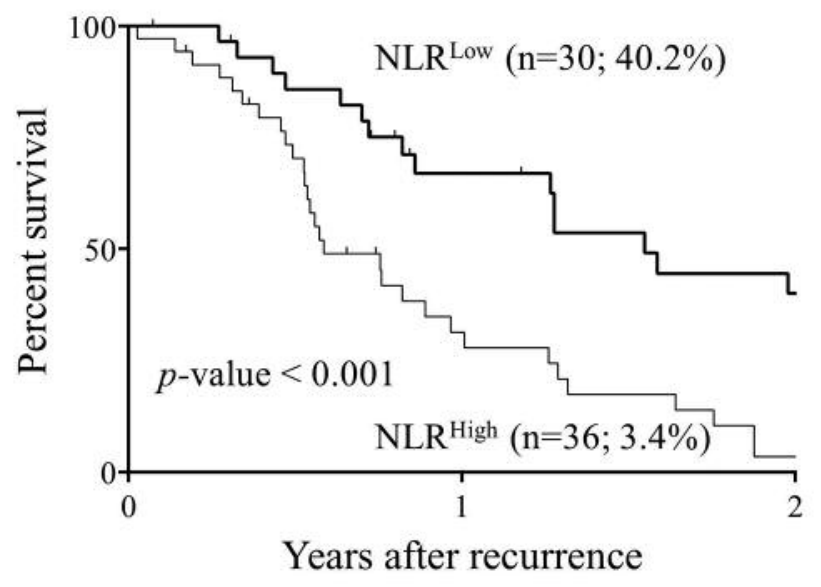

b

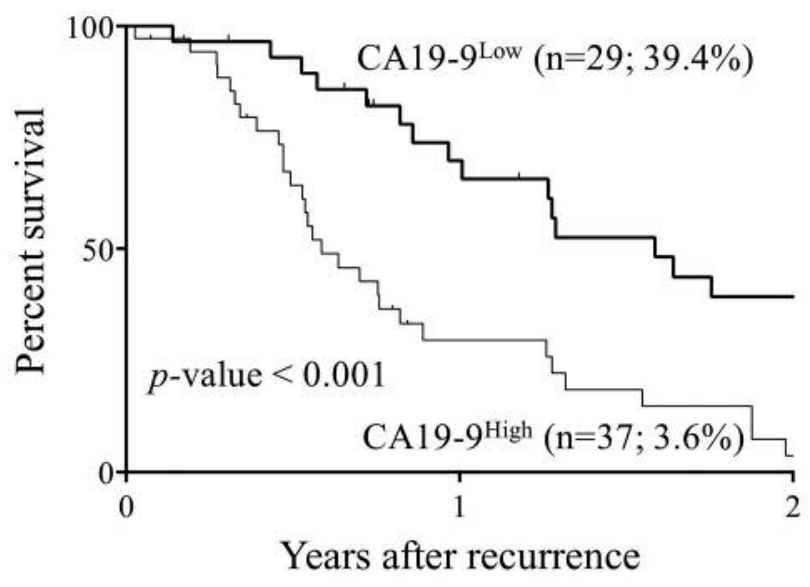

Figure 2. Survival curves of patients with recurrent pancreatic cancer according to NLR (a) and serum CA19-9 level (b).
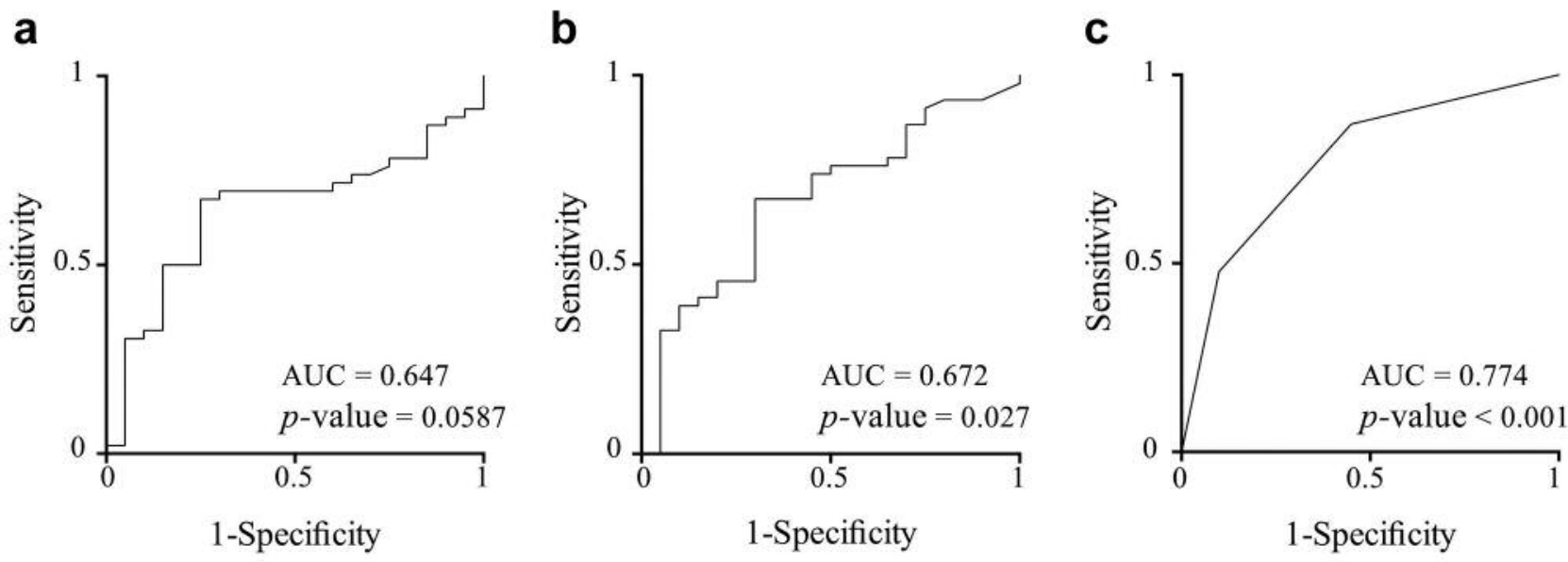

Figure 3. Receiver operating characteristic curves for NLR (a), serum CA19-9 level (b), and the combination of NLR and serum CA19-9 level (c) for the prediction of 2-year survival after recurrence of pancreatic cancer.

T cells, with poor prognosis in cancers (37-39). Furthermore, for both peripheral blood and cancer tissue, low levels of immune cells, such as NK cells, B cells, and gamma-delta T cell have been associated with poor prognosis for some cancer types (40-42). Therefore, peripheral lymphocyte count might be a good indicator of cell-mediated immune status, including both acquired and adaptive immunity, and humoral immune status against PC. Lymphocyte count is also included in the prognostic nutritional index, which is a representative indicator of nutritional status. Poor nutritional status is reportedly related to poor prognosis in cancer patients. Therefore, peripheral lymphocyte count can reflect inflammation, immunity, and nutritional status, all of which may affect prognosis of patients with recurrent PC.
Serum CA19-9 level and NLR were not significantly related in this study. Serum TMs are mainly derived from the cancers themselves, whereas NLR reflects the patient's inflammation, immunity, and nutritional status. Both tumorand patient-centered approaches can help predict prognosis of cancer patients. In addition, the usefulness of combining several tumor- or patient-related factors to predict prognosis in patients with PC has been reported $(43,44)$. The different origins of TMs and NLR suggest that their combination would be superior to either serum CA19-9 level or NLR alone for predicting prognosis of patients with recurrent PC; and indeed, we found that the AUC for 2-year survival of combined serum CA19-9 level and NLR was higher than that of either of them separately. The combination of serum 
Table II. Univariate and multivariate analyses of prognostic factors for overall survival in patients with recurrent pancreatic cancer.

\begin{tabular}{|c|c|c|c|c|c|c|}
\hline \multirow[b]{2}{*}{ Variables } & \multicolumn{3}{|c|}{ Univariate analysis } & \multicolumn{3}{|c|}{ Multivariate analysis } \\
\hline & HR & $95 \% \mathrm{CI}$ & $p$-Value & HR & $95 \% \mathrm{CI}$ & $p$-Value \\
\hline Age $(\geq 70 v s .<70)$ & 1.272 & $0.698-2.319$ & 0.432 & & & \\
\hline Gender (male vs. female) & 1.106 & $0.587-2.085$ & 0.755 & & & \\
\hline Primary tumor size $(\geq 29.5 \mathrm{~mm} v s .<29.5 \mathrm{~mm})$ & 1.538 & $0.847-2.795$ & 0.158 & & & \\
\hline Tumor location (head vs. body and tail) & 1.047 & $0.565-1.941$ & 0.884 & & & \\
\hline Lymph node metastasis (present $v s$. absent) & 2.071 & $1.078-3.978$ & 0.029 & 1.263 & $0.614-2.598$ & 0.526 \\
\hline Lymphatic involvement (ly $0 / 1 v s$. ly $2 / 3)^{\mathrm{a}}$ & 1.520 & $0.807-2.861$ & 0.195 & & & \\
\hline Vascular involvement $(\mathrm{v} 0 / 1 \text { vs. } \mathrm{v} 2 / 3)^{\mathrm{b}}$ & 1.952 & $1.078-3.534$ & 0.027 & 1.253 & $0.661-2.377$ & 0.490 \\
\hline Perineural invasion (ne $0 / 1 v s$. ne $2 / 3)^{\mathrm{c}}$ & 2.020 & $0.723-5.642$ & 0.180 & & & \\
\hline Chemotherapy (present $v s$. absent) & 0.560 & $0.276-1.137$ & 0.108 & & & \\
\hline \multicolumn{7}{|l|}{ Time to recurrence after pancreatectomy } \\
\hline (<12 months $v s . \geq 12$ months) & 2.372 & $1.277-4.523$ & 0.009 & 1.901 & $0.987-3.662$ & 0.055 \\
\hline Combination of NLR and serum CA19-9 level & & & $<0.001$ & & & 0.001 \\
\hline Group C vs. Group A & 7.703 & $3.041-19.512$ & $<0.001$ & 5.912 & $2.229-15.683$ & $<0.001$ \\
\hline Group B vs. Group A & 3.379 & $1.328-8.600$ & 0.011 & 3.077 & $1.195-7.920$ & 0.020 \\
\hline
\end{tabular}

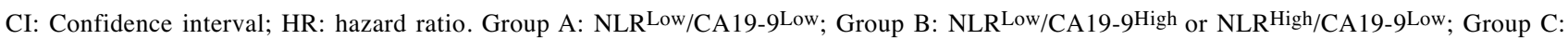
NLR High/CA19-9High. a Lymphatic involvement: ly 0-3, grade of lymphatic vessel invasion; bVascular involvement: $\mathrm{v} 0-3$, grade of venous invasion; cPerineural invasion: ne $0-3$, grade of perineural invasion.

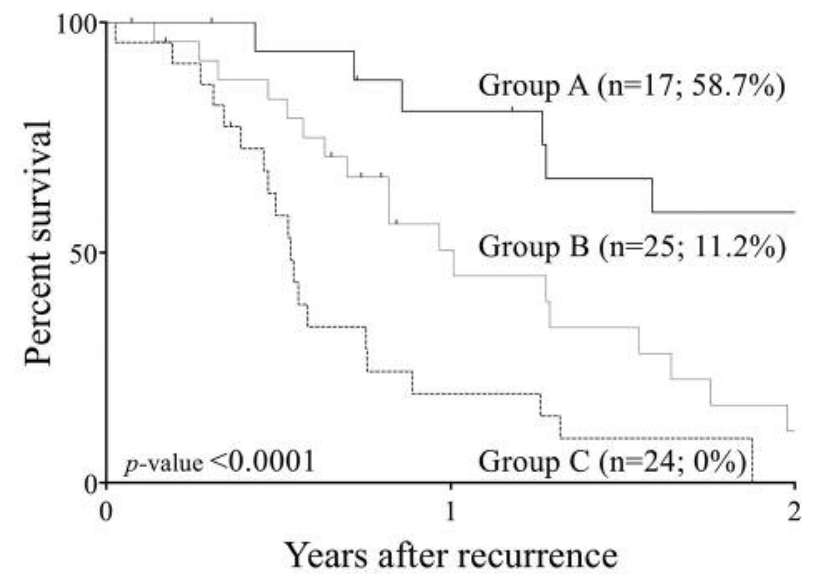

Figure 4. Overall survival curves after recurrence according to the combination of NLR and serum CA19-9 level. Group A: NLR Low/ CA19-9Low; Group B: NLR ${ }^{\text {Low }} / C A 19-9^{\text {High }}$ or NLR High/CA19-9Low; Group C: NLR High/CA19-9High.

CA19-9 level and NLR was also an independent prognostic indicator in our multivariate analysis.

This study has a certain limitations. First, it is a retrospective analysis, which could generate some bias. Second, although NLR and serum CA19-9 level were measured at the time of recurrence, the optimal time to measure them with respect to prognosis remains unclear. Third, the number of patients included in this study was small; a large-scale, prospective study is needed to verify our results.
In conclusion, the combination of NLR and serum CA19-9 level is a useful indicator of recurrent pancreatic cancer prognosis. Because peripheral blood cell count is a quick, easy, and non-invasive assay, combined NLR and serum CA19-9 level could be an inexpensive and practical marker for prognosis of patients with recurrent PC.

\section{References}

1 Torre LA, Bray F, Siegel RL, Ferlay J, Lortet-Tieulent J and Jemal A: Global cancer statistics, 2012. CA Cancer J Clin 65: 87-108, 2015.

2 Vincent A, Herman J, Schulick R, Hruban RH and Goggins M: Pancreatic cancer. Lancet 378: 607-620, 2011.

3 Sperti C, Pasquali C, Piccoli A and Pedrazzoli S: Recurrence after resection for ductal adenocarcinoma of the pancreas. World J Surg 21: 195-200, 1997.

4 Wangjam T, Zhang Z, Zhou XC, Lyer L, Faisal F, Soares KC, Fishman E, Hruban RH, Herman JM, Laheru D, Weiss M, Li M, De Jesus-Acosta A, Wolfgang CL and Zheng L: Resected pancreatic ductal adenocarcinomas with recurrence limited in lung have a significantly better prognosis than those with other recurrence patterns. Oncotarget 6: 36903-36910, 2015.

5 Conroy T, Desseigne F, Ychou M, Bouche O, Guimbaud R, Becouarn Y, Adenis A, Raoul JL, Gourgou-Bourgade S, de la Fouchardiere C, Bennouna J, Bachet JB, Khemissa-Akouz F, Pere-Verge D, Delbaldo C, Assenat E, Chauffert B, Michel P, Montoto-Grillot $\mathrm{C}$ and Ducreux M: FOLFIRINOX versus gemcitabine for metastatic pancreatic cancer. N Engl J Med 364: 1817-1825, 2011.

6 Von Hoff DD, Ervin T, Arena FP, Chiorean EG, Infante J, Moore M, Seay T, Tjulandin SA, Ma WW, Saleh MN, Harris M, Reni 
M, Dowden S, Laheru D, Bahary N, Ramanathan RK, Tabernero J, Hidalgo M, Goldstein D, Van Cutsem E, Wei X, Iglesias J and Renschler MF: Increased survival in pancreatic cancer with nabpaclitaxel plus gemcitabine. N Engl J Med 369: 1691-1703, 2013.

7 Kouri M, Nordling S, Kuusela P and Pyrhonen S: Poor prognosis associated with elevated serum CA 19-9 level in advanced colorectal carcinoma, independent of DNA ploidy or SPF. Eur J Cancer 29a: 1691-1696, 1993.

8 Webb A, Scott-Mackie P, Cunningham D, Norman A, Andreyev $\mathrm{J}$, O'Brien $\mathrm{M}$ and Bensted $\mathrm{J}$ : The prognostic value of serum and immunohistochemical tumour markers in advanced gastric cancer. Eur J Cancer 32a: 63-68, 1996.

9 Shimada H, Nabeya Y, Okazumi S, Matsubara H, Miyazawa Y, Shiratori T, Hayashi H, Gunji Y and Ochiai T: Prognostic significance of CYFRA 21-1 in patients with esophageal squamous cell carcinoma. J Am Coll Surg 196: 573-578, 2003.

10 Ferrone CR, Finkelstein DM, Thayer SP, Muzikansky A, Fernandez-delCastillo C and Warshaw AL: Perioperative CA199 levels can predict stage and survival in patients with resectable pancreatic adenocarcinoma. J Clin Oncol 24: 2897-2902, 2006.

11 Saad ED, Machado MC, Wajsbrot D, Abramoff R, Hoff PM, Tabacof J, Katz A, Simon SD and Gansl RC: Pretreatment CA 19-9 level as a prognostic factor in patients with advanced pancreatic cancer treated with gemcitabine. Int J Gastrointest Cancer 32: 35-41, 2002.

12 Boeck S, Stieber P, Holdenrieder S, Wilkowski R and Heinemann V: Prognostic and therapeutic significance of carbohydrate antigen 19-9 as tumor marker in patients with pancreatic cancer. Oncology 70: 255-264, 2006.

13 Kang CM, Kim JY, Choi GH, Kim KS, Choi JS, Lee WJ and Kim BR: The use of adjusted preoperative CA 19-9 to predict the recurrence of resectable pancreatic cancer. J Surg Res 140: 31-35, 2007.

14 Hartwig W, Strobel O, Hinz U, Fritz S, Hackert T, Roth C, Buchler MW and Werner J: CA19-9 in potentially resectable pancreatic cancer: perspective to adjust surgical and perioperative therapy. Ann Surg Oncol 20: 2188-2196, 2013.

15 Coussens LM and Werb Z: Inflammation and cancer. Nature 420: 860-867, 2002.

16 Mantovani A, Allavena P, Sica A and Balkwill F: Cancer-related inflammation. Nature 454: 436-444, 2008.

17 An X, Ding PR, Li YH, Wang FH, Shi YX, Wang ZQ, He YJ, $\mathrm{Xu}$ RH and Jiang WQ: Elevated neutrophil to lymphocyte ratio predicts survival in advanced pancreatic cancer. Biomarkers 15: 516-522, 2010.

18 Shimada H, Takiguchi N, Kainuma O, Soda H, Ikeda A, Cho A, Miyazaki A, Gunji H, Yamamoto $\mathrm{H}$ and Nagata M: High preoperative neutrophil-lymphocyte ratio predicts poor survival in patients with gastric cancer. Gastric Cancer 13: 170-176, 2010.

19 Chua W, Charles KA, Baracos VE and Clarke SJ: Neutrophil/lymphocyte ratio predicts chemotherapy outcomes in patients with advanced colorectal cancer. British journal of cancer 104: 1288-1295, 2011.

20 Ben Q, An W, Wang L, Wang W, Yu L and Yuan Y: Validation of the pretreatment neutrophil-lymphocyte ratio as a predictor of overall survival in a cohort of patients with pancreatic ductal adenocarcinoma. Pancreas 44: 471-477, 2015.

21 Koh CH, Bhoo-Pathy N, Ng KL, Jabir RS, Tan GH, See MH, Jamaris $S$ and Taib NA: Utility of pre-treatment neutrophil- lymphocyte ratio and platelet-lymphocyte ratio as prognostic factors in breast cancer. Brit J Cancer 113: 150-158, 2015.

22 Namikawa T, Munekage E, Munekage M, Maeda H, Yatabe T, Kitagawa $\mathrm{H}$, Kobayashi $\mathrm{M}$ and Hanazaki $\mathrm{K}$ : Evaluation of systemic inflammatory response biomarkers in patients receiving chemotherapy for unresectable and recurrent advanced gastric cancer. Oncology 90: 321-326, 2016.

23 Garcea G, Ladwa N, Neal CP, Metcalfe MS, Dennison AR and Berry DP: Preoperative neutrophil-to-lymphocyte ratio (NLR) is associated with reduced disease-free survival following curative resection of pancreatic adenocarcinoma. World J Surg 35: 868872, 2011.

24 Japan Pancreas Society: General rules for the study of pancreatic cancer, 7th edition. Kanehara, Tokyo, 2016.

25 Yamamoto Y, Ikoma H, Morimura R, Konishi H, Murayama Y, Komatsu S, Shiozaki A, Kuriu Y, Kubota T, Nakanishi M, Ichikawa D, Fujiwara H, Okamoto K, Sakakura C, Ochiai T and Otsuji E: Optimal duration of the early and late recurrence of pancreatic cancer after pancreatectomy based on the difference in the prognosis. Pancreatology 14: 524-529, 2014.

26 Haruki K, Shiba H, Shirai Y, Horiuchi T, Iwase R, Fujiwara Y, Furukawa K, Misawa $\mathrm{T}$ and Yanaga $\mathrm{K}$ : The $\mathrm{C}$-reactive protein to albumin ratio predicts long-term outcomes in patients with pancreatic cancer after pancreatic resection. World J Surg 40: 2254-2260, 2016.

27 Sionov RV, Fridlender ZG and Granot Z: The multifaceted roles neutrophils play in the tumor microenvironment. Cancer Microenviron 8: 125-158, 2015.

28 Fridlender ZG, Sun J, Kim S, Kapoor V, Cheng G, Ling L, Worthen GS and Albelda SM: Polarization of tumor-associated neutrophil phenotype by TGF-beta: "N1" versus "N2" TAN. Cancer Cell 16: 183-194, 2009.

29 Sun R, Luo J, Li D, Shu Y, Luo C, Wang SS, Qin J, Zhang GM and Feng ZH: Neutrophils with protumor potential could efficiently suppress tumor growth after cytokine priming and in presence of normal NK cells. Oncotarget 5: 12621-12634, 2014.

30 Mroczko B, Groblewska M, Gryko M, Kedra B and Szmitkowski M: Diagnostic usefulness of serum interleukin 6 (IL-6) and C-reactive protein (CRP) in the differentiation between pancreatic cancer and chronic pancreatitis. J Clin Lab Anal 24: 256-261, 2010.

31 Miura T, Mitsunaga S, Ikeda M, Shimizu S, Ohno I, Takahashi H, Furuse J, Inagaki M, Higashi S, Kato H, Terao K and Ochiai A: Characterization of patients with advanced pancreatic cancer and high serum interleukin-6 levels. Pancreas 44: 756-763, 2015.

32 Bergers $G$ and Benjamin LE: Tumorigenesis and the angiogenic switch. Nat Rev Cancer 3: 401-410, 2003.

33 Tazzyman S, Lewis CE, and Murdoch C: Neutrophils: key mediators of tumour angiogenesis. Int J Exp Pathol 90: 222-231, 2009.

34 Clark EJ, Connor S, Taylor MA, Madhavan KK, Garden OJ and Parks RW: Preoperative lymphocyte count as a prognostic factor in resected pancreatic ductal adenocarcinoma. HPB (Oxford) 9: 456-460, 2007.

35 Ray-Coquard I, Cropet C, Van Glabbeke M, Sebban C, Le Cesne A, Judson I, Tredan O, Verweij J, Biron P, Labidi I, Guastalla JP, Bachelot T, Perol D, Chabaud S, Hogendoorn PC, Cassier P, Dufresne A and Blay JY: Lymphopenia as a prognostic factor for overall survival in advanced carcinomas, sarcomas, and lymphomas. Cancer Res 69: 5383-5391, 2009. 
36 Saroha S, Uzzo RG, Plimack ER, Ruth K and Al-Saleem T: Lymphopenia is an independent predictor of inferior outcome in clear cell renal carcinoma. J Urol 189: 454-461, 2013.

37 Galon J, Costes A, Sanchez-Cabo F, Kirilovsky A, Mlecnik B, Lagorce-Pages C, Tosolini M, Camus M, Berger A, Wind P, Zinzindohoue F, Bruneval P, Cugnenc PH, Trajanoski Z, Fridman WH and Pages F: Type, density, and location of immune cells within human colorectal tumors predict clinical outcome. Science 313: 1960-1964, 2006.

38 Gooden MJ, de Bock GH, Leffers N, Daemen T and Nijman HW: The prognostic influence of tumour-infiltrating lymphocytes in cancer: a systematic review with meta-analysis. Brit J Cancer 105: 93-103, 2011

39 Tang Y, Xu X, Guo S, Zhang C, Tang Y, Tian Y, Ni B, Lu B and Wang $\mathrm{H}$ : An increased abundance of tumor-infiltrating regulatory $\mathrm{T}$ cells is correlated with the progression and prognosis of pancreatic ductal adenocarcinoma. PLoS One 9: e91551, 2014.

40 Tachibana T, Onodera H, Tsuruyama T, Mori A, Nagayama S, Hiai $\mathrm{H}$ and Imamura $\mathrm{M}$ : Increased intratumor Valpha24-positive natural killer T cells: a prognostic factor for primary colorectal carcinomas. Clin Cancer Res 11: 7322-7327, 2005.

41 Qiu H, Xiao-Jun W, Zhi-Wei Z, Gong C, Guo-Qiang W, Li-Yi Z, Yuan-Fang L and Rajiv-Prasad K: The prognostic significance of peripheral T-lymphocyte subsets and natural killer cells in patients with colorectal cancer. Hepatogastroenterology 56: 1310-1315, 2009.
42 Berntsson J, Nodin B, Eberhard J, Micke P and Jirstrom K: Prognostic impact of tumour-infiltrating B cells and plasma cells in colorectal cancer. Int J Cancer 139: 1129-1139, 2016.

43 Numata K, Morinaga S, Katayama Y, Sawazaki S, Numata M, Godai T, Higuchi A, Shiozawa M, Rino Y, Masuda M and Akaike M: Combining the Glasgow prognostic score and serum carbohydrate antigen 19-9 level improves the ability to predict early recurrence in resected pancreatic cancer patients receiving adjuvant gemcitabine. Anticancer Res 36: 2467-2474, 2016.

44 Ploquin A, Truant S, Piessen G, Vuagnat P, Baldini C, Cattan S and Hebbar M: Locally advanced or metastatic pancreatic adenocarcinoma: easily available factors of predictive prolonged survival under gemcitabine. In Vivo 31: 731-735, 2017.
Received July 3, 2018

Revised July 16, 2018

Accepted July 17, 2018 